\title{
INCORPORATING MUDARABAH INSTRUMENT AS A MEANS FOR POVERTY ALLEVIATION IN NIGERIA
}

\author{
Ishaaq El-Mubarak, A.M.O. 1 \\ LLM Candidate, Faculty of Law and International Relations, \\ Universiti Sultan Zainal Abidin,Terengganu, Malaysia \\ (Email: abdulmuqadasopeyemi4sure@gmail.com) \\ Abdul Majid Tahir Mohamed ${ }^{2}$ \\ Ph.D, Senior Lecturer, Faculty of Law and International Relations, \\ Universiti Sultan Zainal Abidin, Terengganu, Malaysia \\ (Email: amtmajid@unisza.edu.my)
}

Accepted date: $22-02-2019$

Published date: 10-07-2019

To cite this document: Ishaaq El-Mubarak, A.M.O. \& Mohamed. A.M.T. (2019). Incorporating Mudarabah Instrument as A Means for Poverty Alleviation in Nigeria. International Journal of Law, Government and Communication, 4(15), 101-112.

DOI: $10.35631 / \mathrm{ijlgc} .4150011$

\begin{abstract}
Mudarabah refers to a partnership investment where rabb-ul-mal (financial provider) provides fund to mudarib (entrepreneur) so that the latter may invest the fund in profitable commercial joint-ventures or economic enterprises. Mudarabah products are very significant and offered by almost all Islamic financial institutions. This kind of partnership-investment product is yet to be included as major instrument to be implemented under poverty alleviation programs. Historically, poverty mitigation schemes have been implemented since the birth of independence in Nigeria. Late discovery of Islamic banking concept and products across the nation imparted several challenges on the economy of the country. Different programs had been introduced with the goal of reducing poverty in Nigeria, but none of them showed significant success. Thus, this paper aims at adopting mudarabah instrument into the existing schemes with the hope that poverty will be significantly reduced amid the society. The paper is a qualitative-based research. It uses various documents and content analysis approach to understand and analyse the process of incorporating mudarabah instrument into poverty alleviation programs across the country. Findings showed that the agenda of reducing poverty are achievable if financial institutions and depositors can give their full cooperation on one edge, and proffer their maximum support in incorporating mudarabah instrument on the other. In the light of this, this paper proposes that mudharabah, which is essentially a profit-sharing contract of Islamic banking, should be extended to the ordinary people so that they will become independent in their sustenance. Also, with the implementation of this free-interest mechanism, rich people will be relieved from direct extreme demands with no ideas and projects. Therefore, with a view of moving the country forward economically, people just need to overlook any religion propagating an idea and concentrate on the benefits the instrument will result in after its implementation.
\end{abstract}

Keywords: Mudarabah, Profit-sharing Contract, Free-interest Mechanism, Alleviation of Poverty 


\section{Introduction}

Capturing the existence of destitution in a country like Nigeria is like exploring how every mankind came into this world. Elements including corruption, natural disaster, terrorism, ethnic conflicts, inter-religious disputes contributed considerably in the countable success among individuals dwelling in the Africa continent. This could be understood through the fact that despite the excessive resources surrounding Nigeria, 32 billion dollars' debt is still at the country's neck due to the absence of appropriate management of the national treasures. In fact, poverty problem has been labelled as "widespread and severe" . Hence, indigence is an ambiguous issue which requires sympathetic insight from different angles of study ${ }^{2}$.

As a matter of reality, the enormous level of poverty in Nigeria could also be ascertained through the excessive applicants that applied for $\mathrm{N}$-power opportunity in Nigeria. N-power platform was introduced by federal government of Nigeria with the aim of empowering and employing many job seekers. However, this program was instantly occupied following its establishment and announcement, after witnessing endless and uncontrolled applications from interested candidates ${ }^{3}$. Thereupon, one could easily describe and detect the magnitude of poverty in Nigeria.

In trying to solve the problem of poverty which is otherwise known as undesirable state, it would be logical to eliminate income inequality. This is because if income is not yet balanced in the community, that sect of people receiving salary below the average standard will still be cheated within the society ${ }^{4}$. Moreover, poverty is not only limited to income insufficiency, but also encompasses limitless access to services and social amenities ${ }^{5}$.

Equally, the recent vice president of Nigeria (in person of Yemi Osinbajo) inferred that in spite of various policies and strategies used by the previous government in battling poverty and inequality across the federation, records yet pinpoints that almost 110 million Nigerians are beneath the poverty line track ${ }^{6}$.

Reducing poverty in any given community heavily depends on the stability of the economy and the welfare of the inhabitants. As a matter of fact, economy will definitely experience positive growth if every individual dwelling in a society is engaged with different occupations and businesses ${ }^{7}$. In this regard, Islamic approaches in mitigating poverty and ways of using mudarabah instrument as a means for reducing poverty in Nigeria shall be discussed accordingly in the following paragraphs.

\footnotetext{
${ }^{1}$ World Bank. (1996). "Nigeria: Poverty in the midst of Plenty: The Challenge of Growth, with inclusion in the World Bank Poverty Assessment”. May, Report No. 14733 - UNI. Pg. 3.

${ }^{2}$ Khan M.H. (2000). “Rural Poverty in Developing Countries”. Finance and Development. Washington: IMF. Pg. 7.

${ }^{3}$ Adoyi, A. (2016, June 13). Daily post. Retrieved from daily post: http://www.dailypost.ng/2016/06/13/news papers-you-need-to-know-this-monday-61/

${ }^{4}$ Alao, O. J. 2016. Sociological Approach to Poverty Alleviation Programme in Nigeria. Global Journals Inc. (USA). Vol. 16. Issue. 7. Version 1.0. Pg. 2.

${ }^{5}$ Nation, U. (1994/95). Households below average income: an analysis of the income distribution. London: Department of Work and Pensions. Pg. 4.

${ }^{6}$ Nwabughiogu, 1. (august 20, 2015). Over 100m Nigerians living below poverty line. Lagos: Vanguard News. http://www.vanguardngr.com/2015/08/over-1-million-nigerians-living-below-poverty-line-osinbajo/

${ }^{7}$ United Nations Development Programme. (2001). Nigerian Human Development Report 2000/2001. Millennium Edition. UNDP: Lagos. Pg. 5.
} 


\section{Conceptual Elucidation}

Poverty occurrences are not limited to a particular territory or country, but it is a global problem which can be easily acknowledged from the affected ones without any form of demonstration. CBN authorities framed their own understanding concerning poverty. It is systematically described as a moment where basic needs including food, shelter and clothing are hardly provided for oneself and relatives. The suitable snapshot for this situation is when somebody's status denied him from having direct and adequate access to social, economic, political and resources commitments. In the same token with that, if the person is considerably deprived from benefitting education, health, portable water and sanitation which will definitely upgrade the person's welfare, thereupon, CBN admits that somebody who is in possession of all these above features is really in a state of destitution ${ }^{8}$.

Perhaps, looking at the definition of poverty given by CBN, if the definition is to be applied to inhabitants' status-quo in Nigeria, it is possible that over average Nigerians will be brought to the poverty-line. This is due to the fact that at this particular period, it is seldom to estimate 30 percent Nigerians having access to the aforementioned amenities.

\section{Theoretical Framework for Poverty}

Even though there is no coordinated definition with regards to the concept of poverty among previous researchers, in view of the general nature of poverty itself, some notable factors could still be commonly found among poor people. These factors include:

Those who are incapable of getting themselves involve in the productive process; this are those whose limited financial savings has rendered them useless in the ongoing productive processes amidst the society.

Those whom national economy has failed to provide jobs for; these are the sect of people whose target in securing job is heavily on the economy. However, no matter their respective competency to put food on their table, the economy did not favour them.

Those who are limited basically on discrimination ground; these are the kind of people who are rendered powerless and helpless in the productive process mainly because the law of the land denounces their recognition in the community. The ground of condemnation might be on sex, age or race issues ${ }^{9}$.

Attribute theory; this theory upholds that the arrival of poverty in any given society lies in the hand of the poor people themselves. The basis of this argument is that individual potentials supposed to be the producer of everyone's income. Similarly, individual's calibre and category will as well be determined through one's initiative and composition ${ }^{10}$. Therefore, the matter is left to every individual to react and reflect towards his respective careers.

\section{Proposed Program in Mitigating Poverty in Nigeria}

Several programs had been suggested and tested with the view of vanishing poverty in Nigeria, yet, none of these programs have been able to solve destitution across the federation. One of the earliest examined programs is the "Operation feed the Nation" (OFN) plan launched by Gen

\footnotetext{
${ }^{8}$ Central Bank of Nigeria (CBN). (1999). Nigeria's Development Prospects: Poverty Assessment and Alleviation Study. Research Department in Collaboration with the World Bank. Pp. 20-73.

${ }^{9}$ Edozien, E.C. (1975). "Poverty: Some Issues in Concept and Theory", in Poverty in Nigeria, Proceedings of the Annual Conference of the Nigerian Economic Society (NES). Pp. 1-10.

${ }^{10}$ Ovie, F. F. \& Akpomuvie, O. B. (2011). An Appraisal of Poverty Alleviation Programmes in Nigeria. JORIND (9)1. ISSN 1596-8303. Pg. 299.
} 
Olusegun Obasanjo in 1979. Similarly, Shagari whose goal was also in support of his predecessors in combating poverty introduced another program entitled "The Green Revolution" with the hope of providing more food to the masses ${ }^{11}$.

Although, the recent president of Nigeria ${ }^{12}$ who was once a head of state around 1983-1985 deviated from his successors' sequence of feeding people, and went ahead to inaugurate another entire plan which is battling corruption. That is to say Buhari's past administration under the military regime dis-incorporate poverty alleviation agenda entirely from its national-plans ${ }^{13}$. Whereas the subsequent regime under the control of Gen Ibrahim Babangida in (1985-1993) initiated a poverty alleviation program labelled as "people's bank". The paramount goal of this bank is to provide loans for entrepreneurs through an affordable and permissive approach.

Additionally, Directorate of Food Roads and Rural Infrastructure (DFFRI) program was introduced with the aim of erecting rural roads basically for the safety of food production. Asides that, in line with this goal, "Nigeria Agricultural Land Development Authority (NALDA)" was eventually established with the purpose of improving farmers cultivated land and offering it at a supportive rate to the farmers.

Late Gen. Sani Abacha's regime which occurs within 1993-1998 establishes Family Economic Advancement Programme (FEAP). In an actual fact, the major reason behind the establishment of this program was that Nigeria's name was found among the top 25 poorest countries across the globe $^{14}$. Historically, record shows that FEAP solely subsists from (1998-2000), a period not more than two years. During that point in time, projects under such program were able to offer some aid such as poultry production, garri ${ }^{15}$ manufacturing, soap production and animal husbandry ${ }^{16}$.

Furthermore, in 2006, Chief Olusegun Obasanjo likewise introduced a particular program known as poverty alleviation programme (PAP). Subsequently, the name was converted to National Poverty Eradication Programme (NAPEP) with the target that poverty mitigation process will be monitored right from the grass-root (local level) to the national stage. Various schemes including Youth Empowerment Scheme (YES), Rural Infrastructure Development Scheme (RIDS), Social Welfare Service Scheme (SOWESS) and National Resources Development and Conservation scheme (NRDCS) were incorporated for the sake of eradicating poverty amidst the nation ${ }^{17}$. Despite these efforts, poverty alleviation initiatives have not yielded the expected outcome in Nigeria.

\section{Approaches for Poverty Mitigation in Islam}

For a better understanding on poverty mitigation approaches, Islam classified the approaches into two ways, namely: Lawful earning approach and philanthropic approach.

\footnotetext{
${ }^{11}$ Bank, C. B., \& Projects. (1999). Nigeria Development; poverty Assessment and Alleviation Study. World Bank Projects. p. 15.

12 In person of President Muhammad Buhari, (2015-2019).

${ }^{13}$ Ekong, E. (1991). Rural Development and the persistence of poverty in Nigeria. Uyo: University of Cross River State Press.

14 (World Bank, 2002; http://article.sapub.org/10.5923.j.economics.20120202.02.html_br).

${ }^{15}$ Garri is the granular product obtained by the roasting of fermented and dewatered mash of cassava (Manihot utilisima and Manihot esculanta, Crantz) tuber.

${ }^{16}$ Olaitan, S. E. (2008). Poverty and poverty Alleviation initiatives in Nigeria. Nsukka: Nigerian Educational Research Association.

17 Alao, O. J. (2016). Sociological Approach to Poverty Alleviation Programme in Nigeria. Global Journals Inc. (USA). Vol. 16. Issue. 7. Version 1.0. pg. 4.
} 


\section{Lawful Earning Approach}

One of the possible methods in battling poverty amidst the society is by avoiding excessive dependence on white collar jobs. Islam discourages staying-long in a certain spot for white collar job, when it is obvious that such opportunity is limited. Islamic doctrine recommends that every individual should embark on short or long trip to seek for Allah's generosity. It encourages all sort of permissible activities such as farming, entrepreneurship, animal raising, service providing etc., with the hope that someone's handiwork shall often determines one's source of income. Based on this word of encouragement, Umar bn Khattaab declares that:

"Let not one of you sits down from earning and say $O$ Allah feed me. You know that the heavens neither rain gold nor silver" 18 .

Hence, people are mindfully persuaded to sort for any legal means of upgrading their respective revenue so as to be financially buoyant in providing basic amenities for themselves and their relatives at large.

\section{Philanthropic Approach}

The fundamental objective of this approach is income distribution. Circulating income is regarded as one of the contributory tools in combating poverty. It must be noted that this method absolutely condemns any sort of hoarding ideologies, and strives for wealth pervasion.

The fact that every mankind will not be endowed with all resources that fits their respective needs guaranty the distribution of capitals and ideas among competent individuals. Chapter 32 of Suratul Zukhruf obliges Muslims to assist themselves occasionally, sympathetically and professionally. Allah (SWT) says:

"Is it they who allocate the mercy of your Lord? We have allocated among them their livelihood in the worldly life, and have raised some of them over others in ranks, so that some of them may compulsorily be in charge to work for the other. And the mercy of your Lord is much better than what they accumulate" 19 .

Essentially, it is apt to state that the basic effect and theme of the above injunction is that entrepreneurship and partnership are more beneficial to each other when it comes to socioeconomic activities. It is observed that Mudarabah instrument serves as linkage mechanism which brings rich people much closer to the poor individuals or vice versa.

\section{Significance of the Study}

Generally, three different parties are involved in Islamic banking business. As a matter of fact, entrepreneurs, depositors together with the bank itself collectively form the entire transaction in Islamic banking. In fact, entrepreneur is carefully entrusted with the usage of the capital provided by investors. Depositors are likewise responsible for supplying capitals that will be used to execute projects. While bank as the third party in the contract is assigned as the average user of the fund, and also a middleman between the entrepreneur and the depositor ${ }^{20}$.

Upon a review on written works relating to mudarabah contract, it was revealed that two distinctive contracts exist between the entrepreneur, bank and depositor. One aspect of mudarabah contract involves only the bank and the depositor. While the other aspect encompasses the bank and the user of the capital (entrepreneur). In the former contract, depositor who is otherwise known as (ashaab al-mal) shall provide capital to the financial institution with the aim of investment. This

\footnotetext{
${ }^{18}$ http://www.mazameer.com/vb/showthread.php?t=21529

${ }^{19}$ Suratul Zukhruf: 32.

${ }^{20}$ Wahid, Abu N. M. (1985). "Islamic Bank and a Theory of Optimal Profit Sharing". IS, Vol. XXIV (3). pp. 389 396.
} 
simply means that the bank will act as an entrepreneur in creating or exploring for an idea, transform it into a project, and finally execute it to accumulate profit. While the latter contract on the other edge operates through the bank and entrepreneur. In this case, the bank will not be in the position of an entrepreneur but rather a fund issuer ${ }^{21}$. Besides, it is worth mentioning that both type of contracts will definitely include equitable share of profits.

Interestingly, a point to note from the relationship that exist among the three players in Islamic banking including entrepreneur, depositor and financial institution is that the financial institution who serve as middleman to these parties will be regarded as direct linkage between them. From there, significant contribution of the study arose as to urge the bank through mudarabah contract to connect both parties together so that they will be useful for themselves on one edge, and they will on the other edge jointly eradicate poverty in Nigeria. The bank as a financial entity will help in sharing depositors' capital among entrepreneurs so that every citizen will be engaged with meaningful tasks.

Similarly, in some cases, the need for the bank to search for investors to finance a project which an entrepreneur will execute is irrelevant if bank itself can be a capital owner and issuer. In certain circumstances, bank can directly provide capital to an entrepreneur to complete a project. Although bank's power is limited in such a way that they are not permitted to give any decision about the direction of the project, but just to monitor it. Agreements made during the negotiation stage in respect of profit and loss sharing will not be challenged nor changed at the course of profit distribution ${ }^{22}$. Hence, it is obvious that the concept of mudarabah can play a major role in alleviating poverty in Nigeria.

\section{Nature of Mudarabah}

Moving beyond the conceptual realm of mudarabah, it is important at this juncture to state the nature of mudarabah. Nothing is absolutely wrong in calling this contract a fiduciary relationship (aqd- al-amanah). In principle, mudarib is protectively free from any form of liability connected with the business except if impropriety, carelessness or agreement violation came from nowhere other than the former, thereupon, the mudarib will be held accountable for any irregular and improper event that might have happened. This simply means that the damage shall be shared based on the rate of capital participation. In other words, the aggregate of fund contributed by the parties to the project's execution will be shared through ratio 90:10 between the mudarib and rabbul mal whereby the mudarib who happens to be the causer of the damage shall take 90 percent of the damage, and the latter will maintain the remaining portion. Yet the profit on the other hand will still be divided equally as initially agreed upon by the parties ${ }^{23}$.

As far as contract disconnection is concerned, each party to the contract has the private access to discontinue the dealings at any moment he deems fit. However, this general rule will not function if it was discovered that the mudarib has already started the business in question. Apart from that, the effectiveness of the general rule will not be applicable in the presence of evidence proving that the contracting parties have sealed their business dealings with specific time and date for enforcement and not for premature disconnection. Although, both contractual parties may decide

\footnotetext{
${ }^{21}$ Uzair, Muhammad. (1955). An Outline of Interest-less Banking. Karachi. Pp. 1-21.

${ }^{22}$ Bank Islam Malaysia Berhad (BIMB), Annual Reports 1986 - 1993, Kuala Lumpur. http://www.bankislam.com.my/home/corporate-info/annual-reports/. Accessed on 13 May 2019.

${ }^{23}$ Bank Negara Malaysia. (2015). Mudarabah. Retrieved from http://www.bnm.gov.my/guidelines/05 shariah/Mudarabah.pdf. Accessed on 13 May 2019.
} 
to change the type of mudarabah they select at any point in time either from restricted mudarabah into unrestricted mudarabah or vice versa ${ }^{24}$.

Importantly, it is worthy to note that on a verbal consent of the investor, agent-manager is permitted to incur debt upon the mudarabah fund (istidaanah). Meanwhile the scale of preference between the goods purchased with mudarabah fund is differentiated with the merchandise secured through credit agreement. As for the goods bought on credit, principle of ownership and liability are exempted from such contracts ${ }^{25}$. Whereas, investor together with agent-manager will not in any cases be bound from sharing the risk and profit therein ${ }^{26}$.

\section{Operational Activities of Mudarabah Contract}

Islamic financial institutions as banking business entities have a significant contribution in the formation of mudarabah contract. In some cases, IFI may decide to be rabbul-mal (capital provider). Practically, IFI at times finance a mudarib (entrepreneur) with the mission that the latter will execute a project with that fund. Mudarib in return shall proportionally share the profit that emanate from the venture with IFI. Notwithstanding that, IFI irregularly appears as mudarib (entrepreneur) in certain circumstances whereby investors in this case who are known as capital provider will be in the position of issuing funds to IFI to perform a particular project. Resultantly, the profit will as well be split-up between the parties to the business activities accordingly.

In mudarabah contract, either the capital is presently at investor's position or not, in as much as he is the original owner of the capital in anywhere it is, the contract is likewise considered valid ${ }^{27}$. Moreover, if the capital is on deposit, the agent-manager acting on behalf of the investor may obtain the capital from the depositor with the aim of using it as mudarabah project by switching the status of the capital to mudarabah investment ${ }^{28}$. The case is actually similar to that of debt fund owned by the investor. The only thing the agent-manager will do at this case is to demand the capital from the debtor and used it as mudarabah venture as mutually agreed upon with the investor $^{29}$. Meanwhile, it is however illegitimate to formulate mudarabah contract from a debt fund. A capital which is free from legal-responsibility is undoubtedly the permitted fund in mudarabah.

Maliki jurists on the contrary totally disagree with mudarabah capital emanating from debts, loans and deposits. The rationale behind their rejection is that they consider debts, loans and deposits as a strange and inexistence source of funding a mudarabah project ${ }^{30}$. Therefore, if the above divergence of opinion will be applicable and transform into Nigeria context, considering the fact that Nigerians are adhering to Maliki school of jurisprudence, capitals on debts, loans and deposits are absolutely prohibited in mudarabah contract.

\footnotetext{
${ }^{24}$ Shariah Standard on Mudarabah, Bank Negara Malaysia.

${ }^{25}$ Al-Shaybani, Muhammad b. al-Hasan.(n.d.). "Kitab_al-Asl, Kitab al-Mudarabah". MS. Dar al-Kutub alMisriyyah, Fiqh Hanafi. Pp. 42 -198.

${ }^{26}$ Udovitch, A. L. (1962). "At the Origin of the Western Commenda: Islam, Israel, Byzantium?" Speculum, Vol. XXXVII. pp. 198 - 207.

${ }^{27}$ Al-Sirkasi, Shamsudeen. (1989). Mabsut. Vol. XXII, p. 29; Wahbah, Vol. IV, pg. 845.

${ }^{28}$ Ibid.

${ }^{29}$ Ibid, pp. 29 \& 58 - 59. This arrangement combines a transfer of debt contract (hawalah) with that of mudarabah. Al-Hawalah, literally, implies "transfer". Legally, it is an agreement by which a debtor is freed from a debt by another becoming responsible for it.

${ }^{30}$ Al-Shaybani, Muhammad b. al-Hasan. (n.d.). "Kitab_al-Asl, Kitab al-Mudarabah". MS. Dar al-Kutub alMisriyyah, Fiqh Hanafi. pp. $42-198$.
} 


\section{Expenditures in Mudarabah Contract}

In pursuit of investment completion and greater profit, agent-manager is however permitted to discount all legitimate expenses related to the execution of the project. There is nothing legally wrong in the agent-manager's conduct spending the mudarabah capital in as much as all the spent expenses are done basically for maximizing profits and completing the mudarabah project. Besides, the fact that the agent-manager is in possession of the capital does not warrants him to touch the capital in expenses that is lacking long-journey trip ${ }^{31}$. This simply means that the agentmanager is bound from disturbing the money in a situation whereby he is dwelling with his family at their home-town and not embarking on any travelling purposely because of the investment. It is noteworthy that in such instances, disbursing mudarabah capital for such personal excuses will undoubtedly lead the agent-manager to legal-crime. To avoid that from happening, the agentmanager is strictly recommended to access his private savings for such disbursements ${ }^{32}$.

Notwithstanding that, agent-manager will yet be free from liability if his travelling basis is traceable to mudarabah-contract benefits. In other words, personal expenses including food, shelter and all other necessities shall be deducted from mudarabah capital considering the fact that all the above outlays are done along the journey-race ${ }^{33}$.

\section{Theoretical Framework of Mudarabah}

\section{Agency Theory}

The relationship between financial provider (principal) and entrepreneur (agent) may be established through Principal-Agency theory. The basic challenge in Principal-Agency theory may ensue from the (agent) as the agent will be expected to prioritize principal's interest over his own benefit in the business dealing ${ }^{34}$. It is frequently stated that conflict of interests and lack of equivalent information are among the major problems that constitutes agency theory ${ }^{35}$.

In this theory, principal and agent cooperatively invest into a project which is ably supervised by the agent. The level of efforts expended by the agent will determine the grade of profits that will be earned at the end of the project. Aside that, the theory requires an intermediary, who will monitor the agent's attempt towards the execution of the task. The primary goal of this monitoringjob is to ensure that principal-agent problem is appreciably controlled or eliminated.

During this process, Islamic banks discharge the duty of mediation between firms and fund owners, as commercial banks act as an intermediary between borrowers and lenders ${ }^{36}$. Hence, the present study applied this theory to mudarabah context as the two parties involved will definitely have clash of interests and profits.

\footnotetext{
${ }^{31}$ Ibn Kathir, Imad al-Din Abu al-Fida' Isma'il. (1986). Al-Bidayah wa al-Nihayah. 14 Vols, (in 7), Beirut, Vol. 2. pg. 181.

${ }^{32}$ Al-Khatib, Muhammad al-Sharbini. (1994). Mughni al-Muhtaj ila Ma'arifat Alfaz al-Minhaj. Daarul Kutuub 'Ilmiyyah. Vol. V. pp. 41-42.

${ }^{33}$ Al-Kasani, Ala'u al-Din Abu Bakr b. Mas'uud. 1986. Kitab Bada'i al-Sanaayi'in fi Tartib al-Sharaayi'in. Daarul Kutuub al-'ilmiyyah. Vol. VI. pg. 106.

${ }^{34}$ Lucian Bebchuk and Jesse Fried. 2004. Pay Without Performance. Harvard University Press. (preface and introduction). Retrieved from http://www.paywithoutperformance.com/Preface\%20and\%20Introduction.pdf. Accessed on 27 February 2013.

${ }^{35}$ Muhibat, A. O. et al. (2016). Theoretical Framework and Essence of Effective Regulation of Islamic Banking System. Journal of Islamic Legal Studies. Vol. 2. Issue 1. Pg. 3.

${ }^{36}$ Ibid. pg. 4.
} 
Mudarabah as Development Assistance Tool in Minimizing Poverty in Nigeria: A Discourse As far as poverty alleviation is concerned in any part of the globe, development assistance methods are normally the rightful tools used by Government to accomplish the mission of destitution mitigation in the society. Realistically, it is observed that policies provided in curbing poverty across Nigeria seem not to be effective and productive. In this regard, various outcomes that could be derived in applying mudarabah instrument as an alternative tool in battling poverty shall be highlighted. It is important to note that mudarabah brings the following development benefits.

\section{Reduces Unemployment Rate}

Using the mudarabah instrument in a country like Nigeria will definitely minimize the level of job scarcity in the country. This can be realized if an entrepreneur comes out and develops a particular project or design which is convincing enough to obtain money from the bank. The entrepreneur shall display talents and skills to the masses with the hope that sponsors will fund such an idea through bank's intervention. In fact, deals will be binding between entrepreneurs and sponsors in the presence of talents and funding. Thereupon, poor people with different skills will be getting the attention of rich persons through bank's involvement.

\section{Advances Resource Distribution And Productivity}

Excessive possession of properties by possessor often results to poor maintenance. Weak management commences when someone is unable to recognize the quality of an object. Belongings become useless in the absence of active users. Meanwhile, if an entrepreneur who is otherwise moneyless can create a project describing the value, relevancy and potentiality of that resource, belongings will not only be wasting again, but helpless people will as well be catering for their essential needs concurrently. Besides, sponsors lack ample time to invest these properties, hence, mudarabah will render the service by exploring for suitable avenue to allocate these properties.

\section{Elevate Skills}

Without any shadow of doubt, after some period of time, the availability of fund and constant commitments will have widened entrepreneur's experience and exposure to the extent that beggary ideology would have disappeared in their mind at that moment.

\section{Enhance Wealth Circulation}

Apart from the fact that entrepreneurs will be sufficiently funded, labourers and suppliers executing the project will also benefit from it. Wealth distribution begins when every member associated with the project started receiving their respective entitlement.

\section{Establishes Integration}

Along the line, integration process arose whereby ideas that emanates from entrepreneurs will be combined together with financial institutions which will assuredly leads to economic perfection. Country's economy shall witness massive growth with the combination of different sectors and various human powers.

\section{Encourages People To Work}

Individuals are not willing to work mainly because they are lacking financial assistance to set-up a business. The ideas are there, except that the capital that will transform such idea into material is scanty. Nonetheless, in the presence of fund, their motivation become stronger. One of the beneficial outcomes in introducing mudarabah into the existing program in respect of poverty alleviation is that many people will be eager to become an entrepreneur. Thereupon, needy beings will be vanishing gradually. 


\section{Enhances GDP}

The positive result that might also ensue from this instrument is that the economic performance of the entire country will perceive its existence. Since everyone will have been engaged with diverse projects, the nation at large shall not suffer from production scarcity, money hoarding and goods and services consumption.

\section{Profit-Sharing Contract (Mudarabah) and Business Opportunities in Nigeria}

Economic infrastructures which are the major source that guaranty stable income for ordinary people in the society could be acquired through mudarabah instrument in various aspects. Chances including agriculture sector, animal and livestock, fishing sector, and as well business and entrepreneurship could create many jobs for unemployed candidates across the country. In the light of this, it is of great importance to showcase how the above factors can bring into being variety of offers.

\section{Agriculture Sector}

The largest portion of employment agricultural sector employs makes it a significant sector in the economy ${ }^{37}$. In other words, the kind of unemployed candidates agricultural sector could afford, no other sector throughout the federation can compete with the sector in that aspect. The capacity of agricultural sector to stabilize financial system, provide food, jobs and raw materials renders it a relevant sector in the course of financing projects.

Poverty can as well be tackled through capitalizing farming department. Allocating specific fund to the sector through profit-sharing contract assists the department in purchasing land, constructing buildings, buying farming equipment, employing labourers, irrigating lands and crops, ordering for modern technologies etc ${ }^{38}$. Therefore, sponsor-entrepreneur dealings have a very vital role to play in the agricultural sector if considerably allowed and properly applied.

\section{Animal and Livestock Management}

Undoubtedly, animal and livestock farming require funding. This is traceable to the fact that the primary goal of livestock farming is to nurture animals for food and human usage. Nonetheless, it is worth mentioning that the kind of animals which falls under livestock farming includes cattle, sheep, goat, poultry, camel etc ${ }^{39}$. Among the reason why farmers need to be catered for in this aspect is that consumers' health lies in their hand through the maximum protection they have for these animals while rearing them.

Smith 2001 opines that livestock production is recently regarded as source of income, origin of investment and means of maintenance in Nigeria ${ }^{40}$. Remarkably, it was recorded that majority of the inhabitants dwelling at rural district in Nigeria survive themselves through rearing, marketing and producing livestock ${ }^{41}$. Thus, mudarabah instrument will surely be marketable at this facet.

\footnotetext{
${ }^{37}$ Philip D., Nkonya E., Pender J. and O. A. Oni. (2009). “Constraints to Increasing Agricultural Productivity in Nigerian: A Review”. Nigeria Strategy Support Program (NSSP) Background. Paper No. 6.

${ }^{38}$ Obansa S. A. J \& Maduekwe, I. M. (2013). Agriculture Financing and Economic Growth in Nigeria. European Scientific Journal. January 2013 edition. Vol.9. No.1.

${ }^{39}$ Brown, I. (2001). Dissemination of Information - Review of Literature and Issues. The Library Quarterly. Vol. 37. No. 4. Pp. 373-391.

${ }^{40}$ Smith, S. N. (2001). Utilization of Agricultural Information resources among livestock farmers,

"The basic facts". Journal of Tropical Agriculture. Vol. 22. No. (1). Pg. 1.

${ }^{41}$ Sonaiya, B. (1999). Rural Livestock: An Alternative and Viable Source of Protein. Retrieved

February 2, 2015, from http://www.livestocksite. Com.
} 


\section{Fishing}

This is another factor which can warranty job opportunity in Nigeria. Although, fisheries share in gross domestic production (GDP) might be relatively small in the economy. Nonetheless, it is still considered salient considering the fact that people still feed themselves and increase their respective income through this fisheries business mostly at rural $\operatorname{areas}^{42}$. The potentiality in fishing industry is that it can stir enterprises development, boost rural economies and create job opportunities $^{43}$. Statistically, it was revealed that fishery sector contributes 4 percent out of the overall GDP in Nigeria ${ }^{44}$. The impact of this sector over the sustenance of almost three million people across the country is immeasurable ${ }^{45}$. For these reasons, it is therefore necessary to narrowdown the concept of mudarabah into this axis with the goal that people will not be left jobless amidst the society.

\section{Business and Entrepreneurship}

Working capital is the major element that can assure the effectiveness of a particular business. In other words, the absence of stable and sufficient fund to finance a commercial activity normally slows down the success of any business activities ${ }^{46}$.

As a matter of fact, the concept of entrepreneurship is universally known to everyone to the extent that several Governments normally use it as a tool for generating employment across the federation. Similarly, Nigerian Government likewise adopts it as job-creation mechanism to the magnitude that varieties of enterprises are developed from it. The likes of Agricultural/agro-allied activities which entail foodstuff, restaurants, fast food vending etc. Also, in the part of solid minerals, quarrying, germ stone polishing and crushing engineering could be found therein. Besides that, in the field of information and telecom business, services including manufacturing, printing and selling of Recharge cards, GSM accessories restoration are provided. More so, in hospitality and tourism business, facilities such as hotels, accommodation, resorts centres, film and home video production are supplied. In oil and gas business, pipelines, drilling, refining bye products are being constructed and maintained. As for environmental and waste management business, refuse collection/disposal, recycling, and drainage/sewage construction job are provided. With regards to financial banking services, banking-insurance and stock trading are made available. With reference to engineering and fabrication works, machines and tools fabrication are supplied. Concerning building and construction aspect, plan and design services are as well offered therein ${ }^{47}$. However, notwithstanding these facts in respect of entrepreneurship activities, features like highest rates of youth unemployment and poorest country is still used till date to describe Nigeria. As such, in order to overcome poverty catastrophe across the nation, mudarabah contract is the proper instrument which can eradicate poverty in the country.

\footnotetext{
${ }^{42}$ Reuchlin, J. W. (2012). “The Economic Impacts of Piracy on the Commercial Shipping Industry”. DMPP Research Paper. pp. 23-24.

${ }^{43}$ Peter, O. "Fishing and Nigeria's 2020 Goals for Entrepreneurial Revolution". Vanguard, 3 January, 2011 $<$ http://www.vanguardngr.com/2011/01/fishing-and-nigeria\%E2\%80\%99s-2020-goals-for-entrepreneurialrevolution/> accessed 7 February 2015.

44 "Re-Positioning the Fisheries Sector," a speech delivered by the Honourable Minister of Agriculture and Rural Development, Dr Akinwumi Adeshina on the 25th of February, 2014. Retrieved from $<$ http://www.fmard.gov.ng/news inside/96> accessed 6 December 2014.

${ }^{45}$ Adedeji, O. A. \& Okocha, R.C. (2011). Constraints to Aquaculture Development in Nigeria and Way Forward". Journal of Applied Sciences Research. Vol. 7. No. 7. Pg. 1134.

${ }^{46}$ Rehman, M. U. \& Anjum, N. (2013). Determination of the Impact of Working Ccapital Management on Profitability: An Empirical Study from the Cement Sector in Pakistan. Asian Economic and Financial Review. Vol. 3. No. 3. Pp. 319-332.

${ }^{47}$ Agbeze, C. (2012). Entrepreneurship: The need to create wealth.... Why not now. Ohafia Today. Vol. 2. No. 32. Pp. 7-12.
} 


\section{Conclusion}

Poverty is not limited to a particular environment. Its features could be visualized in any given society provided that deprivation of certain factors is traceable to the person in question. With reference to past events, poverty is not a newly discovered problem across Nigeria. It is a longstanding situation whereby people are found striving for standard living throughout the country.

From an Islamic point of view, poverty can be approached either through lawful earning or philanthropic method. The former will be introduced in a permissible channel, while the latter will come through the distribution of wealth route. Mudarabah is a part and parcel of mu'amalat contract, and as well a product of Islamic banking where two contracting parties agreed on certain prefixed ratio of profit. Entrepreneurship and partnership are equitably useful to each other when it comes to socio-economic activities.

One possible advantage of using mudarabah instrument is that it is often accompanied with various development benefits. Opportunities exist in agriculture sector, animal and livestock sector, fishing sector together with business and entrepreneurship sectors. If all these sectors are properly funded, they will definitely provide jobs for unemployed candidates across the country.

Meanwhile, the unique way to fund the above sectors is by involving three main parties into the long-run dealings. Good combination of entrepreneurs, depositors and financial institutions can make this goal realistic. Bank as a financial entity will play a very vital role in connecting both entrepreneurs and investors together. Moreover, in certain circumstances, banks can also fund projects, investments and sectors. Thus, it is hoped that the battle against poverty shall definitely be victorious through the cooperation of these parties and the implementation of mudarabah instrument. 